\title{
GMR
}

\section{Single nucleotide polymorphisms in the $C X C R 1$ gene and its association with clinical mastitis incidence in Polish Holstein-Friesian cows}

\author{
J. Pokorska' ${ }^{1}$, M. Dusza ${ }^{1}$, D. Kułaj ${ }^{1}$, K. Żukowski ${ }^{2}$ and J. Makulska ${ }^{1}$ \\ ${ }^{1}$ Department of Cattle Breeding, University of Agriculture in Kraków, \\ Kraków, Poland \\ ${ }^{2}$ Department of Animal Genetics and Breeding, \\ National Research Institute of Animal Production, Balice, Poland \\ Corresponding author: J. Pokorska \\ E-mail: j.pokorska@ur.krakow.pl
}

Genet. Mol. Res. 15 (2): gmr.15027247

Received July 17, 2015

Accepted December 8, 2015

Published April 27, 2016

DOI http://dx.doi.org/10.4238/gmr.15027247

\begin{abstract}
The aim of this study was to identify the association between single nucleotide polymorphisms (SNPs) in the bovine chemokine receptor $(C X C R 1)$ gene and the resistance or susceptibility of cows to mastitis. The analysis of the $C X C R 1$ polymorphism was carried out using polymerase chain reaction restriction fragment length polymorphism analysis for six SNP mutations (c. $+291 \mathrm{C}>\mathrm{T}$, c. $+365 \mathrm{~T}>\mathrm{C}, \mathrm{c} .+816 \mathrm{C}>\mathrm{A}, \mathrm{c} .+819 \mathrm{G}>\mathrm{A},+1093 \mathrm{C}>\mathrm{T}$, and $+1373 \mathrm{C}>\mathrm{A})$, of which four were located within the coding region and two in the 3 'UTR region of the CXCR1 gene. Genetic material from 146 Polish HolsteinFriesian cows was analyzed after dividing into two groups depending on the incidence of clinical mastitis. Identified polymorphisms were in linkage disequilibrium and formed two linkage groups. Three haplotypes (CCCATA, TTAGCC, CTCGCC), forming six haplotype combinations, were detected. The logistic regression showed a significant association between the $\mathrm{CC}$ genotype at c. $+365 \mathrm{~T}>\mathrm{C}$ and susceptibility of cows to clinical mastitis $(\mathrm{P}=0.047)$. The frequency of
\end{abstract}


haplotype combination 1/1 (CCCATA/CCCATA) was not significantly higher in cows susceptible to mastitis $(\mathrm{P}=0.062)$. Of the identified SNP mutations, only c. $+365 \mathrm{~T}>\mathrm{C}$ is a nonsynonymous mutation that induces a change in the coded protein [GCC (Ala) to GTC (Val) at the 122nd amino acid]. This amino acid change can result in changes in receptor function, which may be a reason for the increased mastitis incidence observed in cows with polymorphism at this site.

Key words: Chemokine; Interleukin-8 receptor; Inflammation; Udder; Cattle

\section{INTRODUCTION}

Mastitis, an inflammation of the mammary gland, is an economically debilitating disease affecting the dairy industry. This disease is responsible for reduced milk yield in cows, but it also causes losses arising from the need to discard milk that does not comply with sanitary and hygienic standards. Additionally, mastitis generates costs through veterinary services and medicines for infected cows, and often leads to a reduction in herd size due to the need for culling of seriously ill animals. Currently, many researchers worldwide are trying to identify methods to prevent or reduce the spread of mastitis in dairy cattle herds. Since it is observed that some cows are more resistant to mastitis, it is believed that the susceptibility to this disease could be genetically affected. Consequently, the search for genetic markers possibly associated with udder health is being carried out (Nilsen et al., 2009; Ogorevc et al., 2009). The identification of such markers could lead to the selection of mastitis-resistant cows, which would result in improved herd health and increased efficiency of milk production. Because numerous studies have revealed the importance of chemokines and chemokine receptors in inflammatory diseases, the interleukin-8 receptor $\alpha(C X C R 1)$ has been proposed as a candidate marker of mastitis. The chemokine- $\alpha$ receptor affects the activity of neutrophils by inducing their migratory ability to the inflammation site (Paape et al., 2000) which makes it one of the most important components of the innate immune system. Therefore, mutations in the $C X C R 1$ gene may be associated with the susceptibility of animals to mastitis.

Preliminary studies on $C X C R 1$ polymorphism identified five single nucleotide polymorphism (SNP) mutations within the CXCR1 gene (Grosse et al., 1999; Youngerman et al., 2004b; Pighetti and Rambeaud, 2006). Some authors demonstrated an association between CXCR1 gene polymorphism and udder health, evaluated using various parameters (e.g., SCS, somatic cell scores) (Youngerman et al., 2004a; Beecher et al., 2010; Galvão et al., 2011), but others (e.g., Leyva-Baca et al., 2008, Goertz et al., 2009) rejected this hypothesis. Recent studies have indicated a high degree of polymorphism in the CXCRI gene. For example, Pighetti et al. (2012) identified 36 SNPs within the coding and non-coding regions of this gene, whereas Verbeke et al. (2012) found 16 polymorphisms in the coding region alone, of which six had not previously been reported. The $C X C R 1$ gene was proposed as a potential genetic marker in cattle breeding programs by Zhou et al. (2013), who demonstrated an association between four types of SNP mutations within the 550-bp fragment of the putative exon II region of this gene and milk traits, including SCS.

Because previous research on the polymorphism of the $C X C R 1$ gene has provided conflicting results in terms of the number of mutations identified and their association with 
mastitis in cattle, the aim of the present study was to analyze the CXCR1 gene sequence with a focus on SNPs in a population of Polish Holstein-Friesian cows. In addition, the identified polymorphisms were analyzed for their association with the susceptibility or resistance of cows to clinical mastitis.

\section{MATERIAL AND METHODS}

Milk obtained from 146 Polish Holstein-Friesian cows kept at a farm located in southwestern Poland was analyzed. All cows had completed three or four lactations. Information on episodes of clinical mastitis was acquired from AfiFarm Dairy Farm Management Software (SAE Afikim, Kibbutz AFIKIM, Israel). Depending on the incidence of mastitis, the cows were divided into two groups: group I with no episode of mastitis $(\mathrm{N}=74)$, and group II with more than two episodes of mastitis $(\mathrm{N}=72)$.

Genomic DNA was isolated from the cows' milk, using the method developed at the Department of Cattle Breeding, Faculty of Animal Sciences, University of Agriculture in Kraków (Pokorska et al., 2016). The qualitative and quantitative analysis of the isolated DNA was carried out using a NanoDrop 2000 spectrophotometer (Thermo Fisher Scientific, Waltham, Massachusetts USA).

Polymorphism analysis included the exon II sequence of the $C X C R 1$ gene, comprising the coding and 3'UTR regions of the gene (151,327-153,041 bp of AC150887.4, Pighetti et al., 2012). The sequence was divided into three sections (A, B, and C) and a polymerase chain reaction (PCR) restriction fragment length polymorphism analysis was run for each of them.

The PCR mixture $(20 \mu \mathrm{L})$ contained: $2 \mu \mathrm{L}$ 10X PCR buffer, $2.25 \mathrm{mM} \mathrm{MgCl}_{2}, 0.2$ $\mathrm{mM}$ dNTPs, $8 \mathrm{pmol}$ of each primer, $1.75 \mathrm{U}$ Taq polymerase, $10.3 \mu \mathrm{L}$ water, and approx. 150 ng matrix DNA. All reagents were supplied by ThermoScientific. The PCR was carried out on a C1000 thermocycler (Biorad). Each reaction included the following stages: initial denaturation at $95^{\circ} \mathrm{C}$ for $5 \mathrm{~min}$, followed by 34 cycles, with each cycle including denaturation at $95^{\circ} \mathrm{C}$ for $45 \mathrm{~s}$, annealing of primers at temperatures established for each section $\left(59^{\circ} \mathrm{C}\right.$ section $\mathrm{A}, 58^{\circ} \mathrm{C}$ section $\mathrm{B}$, and $62^{\circ} \mathrm{C}$ section $\mathrm{C}$ ) for $30 \mathrm{~s}$, and elongation at $72^{\circ} \mathrm{C}$ for $50 \mathrm{~s}$. The final elongation was carried out at $72^{\circ} \mathrm{C}$ for $7 \mathrm{~min}$. The amplified products were digested with restriction enzymes as recommended by the manufacturer. The obtained restriction fragments were separated on a 3\% agarose gel stained with SYBR Safe dye (Invitrogen). Details of the location of individual mutations within the CXCR1 gene, primer sequences, restriction enzymes used and the lengths of digestion products are presented in Table 1.

Prediction of $C X C R 1$ haplotypes and estimation of their frequencies in the herd, were carried out using HAPLOVIEW (Barrett et al., 2005). Linkage association between loci was studied using PLINK (v. 1.07) (Purcell et al., 2007). To analyze the herd for Hardy-Weinberg genetic equilibrium the chi-square test was applied.

A possible association between single polymorphisms or haplotype combinations and the incidence of clinical mastitis was evaluated by a logistic regression method using PROC LOGISTIC of SAS (SAS Institute Inc., v. 9.2). The relationship between different single polymorphisms and mastitis was analyzed only for mutations c. $+291 \mathrm{C}>\mathrm{T}$ and c. $+365 \mathrm{~T}>\mathrm{C}$. All other identified SNPs were in total linkage disequilibrium $\left(\mathrm{r}^{2}=1.0\right)$ with either one of these mutations, therefore the results would be the same. Group II (cows with more than two episodes of mastitis) was assumed as the reference and results were considered statistically significant at $\mathrm{P} \leq 0.05$. 
Table 1. Polymorphisms within the bovine CXCR1 gene, primer sequences, annealing temperatures and restriction enzymes used for their identification.

\begin{tabular}{|c|c|c|c|c|}
\hline Polymorphism (ss number) & Primer sequence & $\begin{array}{c}\text { Annealing } \\
\text { temperature }\end{array}$ & $\begin{array}{l}\text { Product } \\
\text { size (bp) }\end{array}$ & $\begin{array}{l}\text { Restriction enzyme/ } \\
\text { allele size (bp) }\end{array}$ \\
\hline $\begin{array}{l}\text { CXCR1 c. }+291 \mathrm{C}>\mathrm{T} \\
\text { (ss.1052336005) }\end{array}$ & \multirow[t]{2}{*}{$\begin{array}{l}\text { (A) } \\
\text { F: 5'-CACCATGACAATCATCCTGA-3' } \\
\text { R: 5'-GCAGACTAGGTCGGAGTACG-3' }\end{array}$} & \multirow[t]{2}{*}{$59^{\circ} \mathrm{C}$} & \multirow[t]{2}{*}{592} & $\begin{array}{l}\text { LguI } \\
\text { CC: } 296 \\
\text { CT: } 592,296 \\
\text { TT: } 592\end{array}$ \\
\hline $\begin{array}{l}\text { CXCR1 c. +365T >C } \\
\text { (ss.1052336006) }\end{array}$ & & & & $\begin{array}{l}\text { Eco31I } \\
\text { CC: } 592 \\
\text { CT: } 592,373,219 \\
\text { TT: } 373,219 \\
\end{array}$ \\
\hline $\begin{array}{l}\text { CXCR1 c. }+816 \mathrm{C}>\mathrm{A} \\
\text { (ss.1052336012) }\end{array}$ & \multirow[t]{3}{*}{$\begin{array}{l}\text { (B) } \\
\text { F: 5'-CCGACCTAGTCTGCTACGAG-3' } \\
\text { R: 5'-CCTTGACATGGGACTGTGA-3' }\end{array}$} & \multirow[t]{3}{*}{$58^{\circ} \mathrm{C}$} & \multirow[t]{3}{*}{591} & $\begin{array}{l}\text { Bsp 143I } \\
\text { AA: } 325,164,87,81,21 \\
\text { AC: } 325,238,164,87,81,21 \\
\text { CC: } 238,164,87,21\end{array}$ \\
\hline $\begin{array}{l}\text { CXCR1 c. }+819 \mathrm{G}>\mathrm{A} \\
\text { (ss.1052336007) }\end{array}$ & & & & $\begin{array}{l}\text { SsiI } \\
\text { AA: } 301,129,114,47 \\
\text { AG: } 301,129,114,67,47 \\
\text { GG: } 301,129,67,47\end{array}$ \\
\hline $\begin{array}{l}{ }^{*} \text { CXCR1 } 1+1093 \mathrm{C}>\mathrm{T} \\
\text { (ss.1052336008) }\end{array}$ & & & & $\begin{array}{l}\text { Msp I } \\
\text { CC: } 214,167,138,72 \\
\text { CT: } 286,214,167,138,72 \\
\text { TT: } 286,167,138 \\
\end{array}$ \\
\hline $\begin{array}{l}\text { *CXCR1 +1373C }>A \\
\text { (ss.1052336009) }\end{array}$ & $\begin{array}{l}\text { (C) } \\
\text { F: 5'CTCTGGCCGTTCACAGTC-3' } \\
\text { R: 5'-GATTTTGTGAGCTTGTTGTTAAA-3' }\end{array}$ & $62^{\circ} \mathrm{C}$ & 564 & $\begin{array}{l}\text { AclI } \\
\text { AA: } 564 \\
\text { AC: } 564,328,236 \\
\text { CC: } 328,236 \\
\end{array}$ \\
\hline
\end{tabular}

*Polymorphisms in 3'UTR; in Pighetti et al. (2012), described as *10C $>$ T and *290C $>$ A.

\section{RESULTS AND DISCUSSION}

Six SNPs within the bovine $C X C R 1$ gene, four in the coding region (c. $+291 \mathrm{C}>\mathrm{T}$, c. $+365 \mathrm{~T}>\mathrm{C}$, c. $+816 \mathrm{C}>\mathrm{A}$, and c. $+819 \mathrm{G}>\mathrm{A}$ ) and two in the $3^{\prime} \mathrm{UTR}$ of the CXCR1 gene $(+1093 \mathrm{C}>\mathrm{T}$ and $+1373 \mathrm{C}>\mathrm{A})$ were found. Of the identified mutations, only one affects a change in the coded protein $(\mathrm{c} .+365 \mathrm{~T}>\mathrm{C}$ ) causing the replacement of valine into alanine at position 122 of the amino acid chain. The herd was not in Hardy-Weinberg equilibrium for all mutations $(\mathrm{P}<0.05)$. The frequencies of genotypes and alleles are presented in Table 2.

The prevalence of genotypes for the c. $+291 \mathrm{C}>\mathrm{T}$ and $\mathrm{c} .+365 \mathrm{~T}>\mathrm{C}$ polymorphisms in the two investigated groups of cows (group I and II) was determined. The frequencies of genotypes CC, TT, and CT for the c. $+291 \mathrm{C}>\mathrm{T}$ mutation in group I were $0.43,0.12$, and 0.45 , while they were $0.54,0.08$, and 0.38 in group II, respectively.

In the studied herd, three $C X C R 1$ haplotypes and six haplotype combinations were identified. The most frequent (0.29) was haplotype combination 2/1 (TTAGCC/CCCATA). Similarly, in group I, the most frequent was haplotype combination $2 / 1(0.32)$, while in group II it was haplotype combination 1/1 (CCCATA/CCCATA) (0.33) (Table 3).

Logistic regression showed an association between the c. $+365 \mathrm{~T}>\mathrm{C}$ single nucleotide polymorphisms and the incidence of clinical cases of mastitis. When the $\mathrm{CC}$, rather than the TT genotype, was identified, the odds of having more than two episodes of mastitis was 2.32 times higher compared to remaining healthy $(95 \% \mathrm{CI} 0.93-5.76, \mathrm{P}=0.047)$ (Table 4). The statistical analysis did not indicate an association between SNP c. $+291 \mathrm{C}>\mathrm{T}$ and clinical cases of mastitis (results not shown). 
Table 2. Frequencies of alleles and genotypes for individual mutations within the $C X C R 1$ gene and distribution to the linkage groups.

\begin{tabular}{|c|c|c|c|c|}
\hline \multirow{2}{*}{$\frac{\text { Mutation }}{291 \mathrm{C}>\mathrm{T}}$} & \multirow[t]{2}{*}{ Genotype frequency } & \multicolumn{2}{|c|}{ Allele frequency } & Linkage group \\
\hline & & & \multirow[t]{4}{*}{1} \\
\hline $\mathrm{CC}$ & 0.49 & $\mathrm{C}$ & 0.69 & \\
\hline $\mathrm{CT}$ & 0.41 & $\mathrm{~T}$ & 0.31 & \\
\hline TT & 0.10 & & & \\
\hline \multicolumn{4}{|l|}{$365 \mathrm{~T}>\mathrm{C}$} & \multirow[t]{4}{*}{2} \\
\hline TT & 0.30 & $\mathrm{~T}$ & 0.52 & \\
\hline $\mathrm{TC}$ & 0.44 & $\mathrm{C}$ & 0.48 & \\
\hline $\mathrm{CC}$ & 0.26 & & & \\
\hline \multicolumn{4}{|l|}{$816 C>A$} & \multirow[t]{4}{*}{1} \\
\hline $\mathrm{CC}$ & 0.49 & $\mathrm{C}$ & 0.69 & \\
\hline $\mathrm{CA}$ & 0.41 & $\mathrm{~A}$ & 0.31 & \\
\hline AA & 0.10 & & & \\
\hline \multicolumn{4}{|l|}{$819 \mathrm{G}>\mathrm{A}$} & \multirow[t]{4}{*}{2} \\
\hline GG & 0.30 & $\mathrm{G}$ & 0.52 & \\
\hline GA & 0.44 & $\mathrm{~A}$ & 0.48 & \\
\hline $\mathrm{AA}$ & 0.26 & & & \\
\hline \multicolumn{4}{|l|}{$1093 \mathrm{C}>\mathrm{T}$} & \multirow[t]{4}{*}{2} \\
\hline $\mathrm{CC}$ & 0.30 & $\mathrm{C}$ & 0.52 & \\
\hline $\mathrm{CT}$ & 0.44 & $\mathrm{~T}$ & 0.48 & \\
\hline TT & 0.26 & & & \\
\hline \multicolumn{4}{|l|}{$1373 \mathrm{C}>\mathrm{A}$} & \multirow[t]{4}{*}{2} \\
\hline $\mathrm{CC}$ & 0.30 & $\mathrm{C}$ & 0.52 & \\
\hline $\mathrm{CA}$ & 0.44 & $\mathrm{~A}$ & 0.48 & \\
\hline AA & 0.26 & & & \\
\hline
\end{tabular}

Table 3. CXCR1 haplotype and haplotype combination frequencies.

\begin{tabular}{l|c|l|c|c|c}
\hline Haplotype & $\begin{array}{c}\text { Haplotype } \\
\text { frequency }\end{array}$ & Haplotype combination & $\begin{array}{c}\text { Haplotype combination } \\
\text { frequency (in herd) }\end{array}$ & $\begin{array}{c}\text { Haplotype combination } \\
\text { frequency in group I* }\end{array}$ & $\begin{array}{c}\text { Haplotype combination } \\
\text { frequency in group II* }\end{array}$ \\
\hline 1(CCCATA) & 0.493 & $1 / 1$ (CCCATA/CCCATA) & 0.26 & 0.19 & 0.33 \\
\hline 2(TTAGCC) & 0.308 & $2 / 1($ TTAGCC/CCCATA) & 0.29 & 0.32 & 0.26 \\
\hline 3 (CTCGCC) & 0.199 & $3 / 1$ (CCCTCCAGCTAC) & 0.17 & 0.18 & 0.17 \\
\hline & & $2 / 2$ (TTAGCC/TTAGCC) & 0.10 & 0.12 & 0.12 \\
\hline & & 2/3(TTAGCC/CTCGCC) & 0.12 & 0.11 \\
\hline & & $3 / 3$ (CTCGCC/CTCGCC) & 0.05 & 0.07 & 0.04 \\
\hline
\end{tabular}

*Group I: cows with no episode of mastitis (in three or four completed lactations); group II: cows with more than two episodes of mastitis (in three or four completed lactations)

Table 4. Association between the c. $365 \mathrm{~T}>\mathrm{C}$ point mutation of the $C X C R 1$ gene and the incidence of mastitis.

\begin{tabular}{l|c|c|c}
\hline CXCR1 c.365T $>$ C genotype & Odds ratio & $95 \%$ CI & P value \\
\hline CC $v$ TT & $\mathbf{2 . 3 1 9}$ & $0.934-5.760$ & $\mathbf{0 . 0 4 7}$ \\
\hline CT $v$ TT & 1.134 & $0.516-2.492$ & 0.380 \\
\hline
\end{tabular}

Despite the higher frequency of haplotype combination $1 / 1$ in group II $(0.33)$ than in group I (0.19), the results of the regression analysis (not shown) did not reveal a statistically significant association between this haplotype combination and mastitis susceptibility ( $\mathrm{P}$ $=0.062)$. Similarly, other haplotype combinations did not affect the incidence of mastitis. A higher frequency of haplotype combination $1 / 1$ in mastitis-susceptible cows is probably connected with the occurrence of the CC genotype for c. $+365 \mathrm{~T}>\mathrm{C}$ mutation in this combination. Thus, the results presented here indicate that the CC genotype may contribute to the increased incidence of clinical mastitis in cows. 
In the investigated cow herd, mutations c. $+291 \mathrm{C}>\mathrm{T}$ and c. $+816 \mathrm{C}>\mathrm{A}$ were in complete linkage (linkage group 1), similarly to mutations c. $+365 \mathrm{~T}>\mathrm{C}, \mathrm{c} .+819 \mathrm{G}>\mathrm{A},+1093 \mathrm{C}>\mathrm{T}$, and $+1373 \mathrm{C}>\mathrm{A}$ (linkage group 2) (Table 2). The linkage of these mutations has previously been demonstrated by Pighetti et al. (2012). They categorized mutations c. +291 and c. +816 into one group, and mutations c. +365 , c. $+819,+1093$ (in Pighetti et al., 2012 designated as *10), and +1373 (in Pighetti et al., 2012, designated as $* 290$ ) into the other group. Therefore, identification of polymorphism at two positions from different linkage groups (e.g., c. +291 and c.+365) is sufficient to identify nucleotides at the remaining polymorphic positions of the CXCR1 gene. Consequently, it is possible to determine the genotype of a cow using just two restriction enzymes, which significantly reduces costs and time of analysis.

To date, several analyses of CXCR1 gene polymorphism and its association with the incidence of mastitis in different cattle breeds have been carried out worldwide. All mutations identified in the present study have been previously described by Pighetti et al. (2012), and four of them (c. $+291 \mathrm{C}>\mathrm{T}, \mathrm{c} .+365 \mathrm{~T}>\mathrm{C}, \mathrm{c} .+816 \mathrm{C}>\mathrm{A}$, and c. $+819 \mathrm{G}>\mathrm{A}$ ) by Verbeke et al. (2012). In addition, the c. $+816 \mathrm{C}>\mathrm{A}$ and $\mathrm{c} .+819 \mathrm{G}>\mathrm{A}$ mutations were described by Youngerman et al. (2004a,b) as +858 and +861 , respectively. Zhou et al. (2013) found four polymorphisms within the exon II sequence of the CXCR1 gene in Chinese native cattle and two of them (c. $+291 \mathrm{C}>\mathrm{T}$ and c. $+365 \mathrm{~T}>\mathrm{C}$ ) were also identified in this study.

The association between the CXCRI gene polymorphism (more precisely, SNP $+735 \mathrm{C}>\mathrm{G}$, previously described as $+777 \mathrm{C}>\mathrm{G}$ ) and mastitis, has been demonstrated by both Youngerman et al. (2004a) and Galvão et al. (2011). Youngerman et al. (2004a) observed a reduced incidence of subclinical mastitis (evaluated based on bacteria isolated from the udder) in cows expressing genotype GG, while Galvão et al. (2011) found a decreased incidence of clinical mastitis (evaluated based on the abnormal appearance of milk or udder) in cows with genotypes CC and GC. Beecher et al. (2010) revealed the association of the G allele with reduced SCS in cows of five breeds, but not in Holstein-Friesian bulls. The influence of mutation $+735 \mathrm{C}>\mathrm{G}$ on mastitis evaluated based on SCS was not confirmed neither by Leyva-Baca et al. (2008) nor by Goertz et al. (2009). Likewise, Verbeke et al. (2012) did not find any association between the identified CXCR1 gene polymorphism and SCC. They only observed an increased resistance to mastitis caused by certain pathogens (i.e., major pathogens: Staphylococcus aureus, $S$. agalactiae, S. dysgalactiae, and esculin-positive streptococci) in cows with genotype AG instead of GG at position c.980. The association of the individual mutations and combined genotypes of the $C X C R 1$ gene (formed by four identified SNP mutations: c.291C > T, c.333C > T, c.337A>G, and c.365C $>$ T) with reduced SCS was found by Zhou et al. (2013).

In the present study, the relationship between $\mathrm{CC}$ genotype for the c.365T $>\mathrm{C}$ mutation and increased mastitis incidence, observed in the Polish population of Holstein-Friesian cows, was confirmed statistically for the first time. On the other hand, Zhou et al. (2013) revealed a significant association of TT genotype for this mutation (and also AA genotype for c.337A $<\mathrm{G}$ mutation, not found in the present study) with higher SCS and a suggested possible role of these two mutations in the host response against mastitis. This discrepancy in the obtained results indicates the need for further research to verify the influence of the c.365T $>$ C mutation on mastitis in cows.

Research by Pighetti et al. (2012) revealed that the CXCR1 c.+365T nucleotide and the $C X C R 1 \mathrm{c} .+735 \mathrm{C}$ nucleotide occur together (because they form a haplotype). Considering that Youngerman et al. (2004a) reported the association between the CXCRI c. +735 (former CXCR2 c. +777) polymorphism and subclinical mastitis in Holsteins, both of these mutations may be crucial for determination of mastitis. 
The c.365T $>\mathrm{C}$ point mutation of the $C X C R 1$ gene leads to a switch from alanine to valine at position 122 in the first extracellular loop, near the transmembrane domain of the CXCR1 G-protein coupled receptor (Pighetti et al., 2012). Because this protein is a receptor for interleukin-8, a key regulator of neutrophil migration, killing and survival (Glynn et al., 2002), this amino acid replacement potentially influences neutrophil function (a change in shape could modify the response to the ligand) and disease resistance. In addition, the protein and mRNA expression levels of interleukin-8 have been associated with bovine mastitis (Lee et al., 2006), which suggests participation of this chemokine in the process of developing the disease.

\section{CONCLUSIONS}

In conclusion, the obtained findings suggest that the $C X C R 1 \mathrm{c} .365 \mathrm{~T}>\mathrm{C}$ mutation can be potentially considered a novel candidate genetic molecular marker for mastitis resistance/ susceptibility and cows with genotype TT should probably be selected in breeding programs as more resistant to mastitis.

\section{Conflicts of interest}

The authors declare no conflict of interest.

\section{ACKNOWLEDGMENTS}

The authors wish to acknowledge financial support from the Ministry of Science and Higher Education in Poland (DS \#3259/2014 and DS \#3258/14).

\section{REFERENCES}

Barrett JC, Fry B, Maller J and Daly MJ (2005). Haploview: analysis and visualization of LD and haplotype maps. Bioinformatics 21: 263-265.http://dx.doi.org/10.1093/bioinformatics/bth457

Beecher C, Daly M, Childs S, Berry DP, et al. (2010). Polymorphisms in bovine immune genes and their associations with somatic cell count and milk production in dairy cattle. BMC Genet. 11: 99.http://dx.doi.org/10.1186/1471-2156-11-99

Galvão KN, Pighetti GM, Cheong SH, Nydam DV, et al. (2011). Association between interleukin-8 receptor- $\alpha$ (CXCR1) polymorphism and disease incidence, production, reproduction, and survival in Holstein cows. J. Dairy Sci. 94: 2083-2091.http://dx.doi.org/10.3168/jds.2010-3636

Glynn PC, Henney E and Hall IP (2002). The selective CXCR2 antagonist SB272844 blocks interleukin-8 and growthrelated oncogene-alpha-mediated inhibition of spontaneous neutrophil apoptosis. Pulm. Pharmacol. Ther. 15: 103110.http://dx.doi.org/10.1006/pupt.2001.0323

Goertz I, Baes C, Weimann C, Reinsch N, et al. (2009). Association between single nucleotide polymorphisms in the CXCR1 gene and somatic cell score in Holstein dairy cattle. J. Dairy Sci. 92: 4018-4022.http://dx.doi.org/10.3168/ jds.2008-1536

Grosse WM, Kappes SM, Laegreid WW, Keele JW, et al. (1999). Single nucleotide polymorphism (SNP) discovery and linkage mapping of bovine cytokine genes. Mamm. Genome 10: 1062-1069.http://dx.doi.org/10.1007/s003359901162

Lee JW, Bannerman DD, Paape MJ, Huang MK, et al. (2006). Characterization of cytokine expression in milk somatic cells during intramammary infections with Escherichia coli or Staphylococcus aureus by real-time PCR. Vet. Res. 37: 219-229.http://dx.doi.org/10.1051/vetres:2005051

Leyva-Baca I, Schenkel F, Martin J and Karrow NA (2008). Polymorphisms in the 5' upstream region of the CXCRI chemokine receptor gene, and their association with somatic cell score in Holstein cattle in Canada. J. Dairy Sci. 91: 407-417.http://dx.doi.org/10.3168/jds.2007-0142

Nilsen H, Olsen HG, Hayes B, Nome T, et al. (2009). Characterization of a QTL region affecting clinical mastitis and protein yield on BTA6. Anim. Genet. 40: 701-712.http://dx.doi.org/10.1111/j.1365-2052.2009.01908.x 
Ogorevc J, Kunej T, Razpet A and Dove P (2009). Database of cattle candidate genes and genetic markers for milk production and mastitis. Anim. Genet. 40: 832-851.http://dx.doi.org/10.1111/j.1365-2052.2009.01921.x

Paape MJ, Shafer-Weaver K, Capuco AV, Van Oostveldt K, et al. (2000). Immune surveillance of mammary tissue by phagocytic cells. Adv. Exp. Med. Biol. 480: 259-277.http://dx.doi.org/10.1007/0-306-46832-8 31

Pighetti GM and Rambeaud M (2006). Genome conservation between the bovine and human interleukin- 8 receptor complex: improper annotation of bovine interleukin-8 receptor b identified. Vet. Immunol. Immunopathol. 114: 335 340.http://dx.doi.org/10.1016/j.vetimm.2006.08.008

Pighetti GM, Kojima CJ, Wojakiewicz L and Rambeaud M (2012). The bovine CXCR1 gene is highly polymorphic. Vet. Immunol. Immunopathol. 145: 464-470.http://dx.doi.org/10.1016/j.vetimm.2011.09.012

Pokorska J, Kułaj D, Żychlińska-Buczek J and Makulska J. (2016). New rapid method of DNA isolation from milk somatic cells. Anim. Biotechnol. 27: 113-117.

Purcell S, Neale B, Todd-Brown K, Thomas L, et al. (2007). PLINK: a tool set for whole-genome association and population-based linkage analyses. Am. J. Hum. Genet. 81: 559-575.http://dx.doi.org/10.1086/519795

Verbeke J, Piepers S, Peelman L, Van Poucke M, et al. (2012). Pathogen-group specific association between CXCR1 polymorphisms and subclinical mastitis in dairy heifers. J. Dairy Res. 79: 341-351.http://dx.doi.org/10.1017/ $\underline{\text { S0022029912000349 }}$

Youngerman SM, Saxton AM, Oliver SP and Pighetti GM (2004a). Association of CXCR2 polymorphisms with subclinical and clinical mastitis in dairy cattle. J. Dairy Sci. 87: 2442-2448.http://dx.doi.org/10.3168/jds.S0022-0302(04)73367-6

Youngerman SM, Saxton AM and Pighetti GM (2004b). Novel single nucleotide polymorphisms and haplotypes within the bovine CXCR2 gene. Immunogenetics 56: 355-359.http://dx.doi.org/10.1007/s00251-004-0699-5

Zhou L, Wang HM, Ju ZH, Zhang Y, et al. (2013). Association of novel single nucleotide polymorphisms of the CXCR1 gene with the milk performance traits of Chinese native cattle. Genet. Mol. Res. 12: 2725-2739.http://dx.doi. org/10.4238/2013.July.30.10 